\title{
THE NATURAL ENVIRONMENT IN THE SUSTAINABLE DEVELOPMENT OF TOWNS: THE EXAMPLE OF POZNAŃ
}

\author{
Lidia Mierzejewska \\ Institute of Socio-Economic Geography and Spatial Management, \\ Adam Mickiewicz University, Fredry 10, 6I-70I Poznań, Poland \\ e-mail: mierzeja@amu.edu.pl
}

\begin{abstract}
In the eighties the environmental elements air, water and soils were examined in correlation with the situation of economic development. In the nineties green areas, which are particularly important for Poznan, were planned within the framework of the General urban planning of the town. In the article, natural factors are represented as restrictive development factors. In the questionnaire, over $83 \%$ of the inhabitants of Poznan pointed out green areas to be the most important factor with regard to further house building.
\end{abstract}

Key words: Poznan, environmental protection, green areas, urban planning, sustainable development.

\section{INTRODUCTION}

The deteriorating status of the particular elements of the natural environment, like air, water and soil, as well as the declining biological diversity observed since the mid-1980s, were thought, and with some justice, to be associated with progressing economic development. It turned out, however, that it was not only human activity that affected nature adversely, but also, that there was negative feedback - the transformed nature had a detrimental effect on man. The repair policy of limiting the emission of pollution in some countries and increaseing investment in environment protection turned out to be insufficient. It was necessary to work out a new conception of development, which would be able to reconcile economic goals with ecological ones. The conception has been that of sustainable development in which the natural environment plays a key role. Its quality largely determines the directions of socio-economic and spatial development, both at the global and local scales. This refers especially to metropolitan areas and industrial regions in which natural elements have, until recently, played a role subordinate to an artificial, man-made environment. 
Poland is a country that recognized the need to reconcile economic development with environmental requirements as far back as 1989. The new 1997 Constitution states that Poland ensures environmental protection by adhering to the principle of sustainable development understood as socio-economic development whose specific feature is the integration of political, economic and social actions while preserving the natural equilibrium and the permanence of natural processes. Sustainable development is also the basic aim of space management put down in the Spatial Development Act. All territorial units, hence also all towns, are statutorily obligated to implement the policy of sustainable development in their areas.

The aim of the present paper is to indicate the role that the natural environment plays in the spatial-functional system of one of Poland's major cities, Poznań, and to see whether the city's current spatial development strategy and plans can actually make it sustainable.

\section{RESEARCH ASSUMPTIONS}

The planning of urban development involves a suitable shaping of relations holding among its basic elements, that is, in terms of the systems conception, the natural and the man-made socio-economic subsystem (Chojnicki 1971). The most important among those relations are the impact of the socio-economic sphere on nature, and of nature on man. It is the formation of these two relations that will decide if a town's development is going to be sustainable, that is to say, is its economic growth is going to be achieved at the cost of environmental quality or not. This is so because the dominance of the socio-economic subsystem in towns is the most important factor disturbing the equilibrium of the entire system (Chojnicki, 1971; Parysek, 1997; Mierzejewska 2001, and others). However, urban development would not be balanced either if the economy were made subordinate to nature. This model of development can only apply to areas of outstanding natural value.

Keeping a balance in the highly specific urban system is not easy, because the relations there are not autonomous; they form a man-environment-man feedback system (Chojnicki, 1988, Mierzejewska, 2001). This results from the heterogeneous nature of the city, which is composed primarily of man-made elements blended inextricably with and embedded in a subsystem created by nature (Regulski, 1982). These subsystems are complementary, but they also compete with each other for urban space. Too often, however, natural elements lose the struggle and are pushed farther and farther away beyond the city limits (Mierzejewska, 2001). Hence, in sustainable development one should strive to maintain the correct proportions between built-up and open areas, and thus to preserve a better quality of the city's living space.

According to the natural model of the urban spatial structure, the state of equilibrium in a city can only be obtained if green spaces of a suitable shape and size and a high degree of conformity to natural conditions are accommodated in its spatial structure (Czerwieniec, Lewińska, 1996). As a result, the natural environment has acquired an almost supreme function in the evaluation of the living conditions of the urban population (Mierzejewska, 2001). Such a crucial role ascribed to natural elements in cities, especially their green areas, probably results from the functions they play. 
Because of the significance of natural elements in the urban spatial structure, there are two basic assumptions underlying all models and designs involved in the planning of this structure:

1. open spaces, left in their natural state or specially developed, are an indispensable component of man's environment; and

2. it is necessary to draw up an integrated plan of the development of a city's spatial structure accommodating both, built-up areas and green spaces.

It is in man's own long-term interest, both economic and ecological, to maintain a high quality of the natural environment (Mierzejewska, 2001).

\section{MAN'S ATTITUDE TOWARDS THE NATURAL ENVIRONMENT}

The choice of a development strategy in an area, including a city, is the resultant of many factors, among which is a culture-determined situational context (von der Wurff 1992). This context greatly affects man's perception of nature, especially of how human life depends on the properties of the environment. Four basic attitudes towards nature can be distinguished (Achterberg 1986; Mierzejewska 2001; Mierzejewska, Parysek, 2001):

1. a 'dominion-over-nature' attitude, an extreme opinion holding that nature and man develop independently of each other. Nature is only perceived as a resource which man has the right to use arbitrarily to satisfy his needs;

2. a 'stewardship' attitude, a different view in the light of which man's existence depends to an extent on the natural conditions, hence there is an interrelationship between the development of man and nature. Nature has more than a utility value, hence it should be treated with care and responsibility;

3. an environment-oriented attitude, in which man is seen as an element of a larger ecosystem. On the one hand, human existence depends on natural conditions, and on the other, nature is perceived as an independent partner with its own autonomy and susceptibility. A consequence is moral regard for the various forms of life sharing the same ecosystem with man; and

4. a 'unity-with-nature' attitude, another extreme in the classification, represented by proponents of so-called 'deep ecology' according to which nature develops autonomously, independently of man, while man is fully dependent on natural processes. Hence, nature has an intrinsic value, and man has a moral obligation to respect it.

Until the mid-1980s, the dominion-over-nature approach seemed to predominate in the development strategies of towns and regions. Scientific and technological progress helped man to strive for independence from nature, made him try to subdue it, and to use it indiscriminately for his own purposes. The results were, and in some regions still are, a rapid rate of urbanisation, an increase in the volume of traffic, and damage to natural ecosystems, which led to a deterioration in man's living conditions (Bauman 1991). Today, when measures are being taken to restore proper ecological relations, this attitude is out of the question. Equally hard to accept would be an arrangement of the living environment leading to 
man's unity with nature, since this attitude negates the sense of progress and man's advancement as a species and a cultural being.

In this day and age, with attempts to balance natural, social and economic relations in towns and urbanised areas, the most desirable are the stewardship or nature-oriented approaches. The latter, however, is only applicable to regions being developed less intensively than metropolitan areas.

\section{GREEN AREAS IN THE SPATIAL STRUCTURE OF POZNAŃ}

The importance of green spaces as an element shaping the climate and sanitary conditions of a city depends largely on whether these spaces form a temporal and spatial continuity in the city. Such continuity in ecosystems means the possibility of alimentation and natural succession (Czerwieniec, Lewińska, 1996). In turn, a decomposition of the pattern of greenery, often accompanied by deterioration in the general state of the natural environment in cities, limits their ecological capacities considerably, especially their capacity for selfregulation (Gaczek, 1992). Hence, for green spaces to perform the functions intended, they should be designed to form a system adjusted, on the one hand, to the urban layout and on the other, to the city's physical-geographic conditions (Czarnecki, 1961). That is why the most desirable are green spaces as extensive as possible, causing air inversions (Myczkowski, Grabowski, 1974) and forming a sort of spatial stretches or environmental corridors (Gacka-Grzesikiewicz, Różycka, 1975). A correctly designed and realised system of greenery blending with suburban green spaces ensures the city proper airing, which has a beneficial effect on the sanitary conditions in which its residents live.

Poznań's green spaces are of crucial importance for the city itself and its residents, because they not only determine the above-mentioned sanitary conditions but also provide a basis for the city's spatial structure.

\section{Pattern of Poznań's green spaces}

The pattern of green spaces in Poznan is based on a ring-wedge conception worked out in 1943 by a team headed by Prof. W. Czarnecki. Wedges forming a Maltese cross based on areas unfit for building in the valleys of the Warta, Bogdanka and Cybina are park-like in the city centre and woodland-like farther away. The design also included three concentric rings of greenery around the city, but after the Second World War the rings underwent degradation and fragmentation owing to uncontrolled building and other investment. Even so, in the early 1970s the wedge pattern of Poznan greenery was considered the best planned and shaped one among not only Polish, but also European cities (cf. Fig. 1). The wedge conception has basically been maintained until today (Mierzejewska, Parysek 1998; Mierzejewska, 2001).

Beneficial for the city though it is, the wedge greenery pattern gives also rise to many functional conflicts resulting largely from a neighbourhood clashing with urban natural areas. Another disadvantage is its limited access to the residents of the city centre. For them, 
therefore, many parks and green squares have been laid out in the centre utilising $19^{\text {th }}$-century fortifications and walls, as well as broad tree-lined avenues (Kepel, 2002). The most important element of these green spaces is the former Citadel, now, at 100 ha, Poznań's biggest park. Most green spaces in the city centre are small, however, hence recreation in them is somewhat hampered, largely by the nearness of many communication routes.

Figure 1: Green wedges in Poznań's spatial structure.

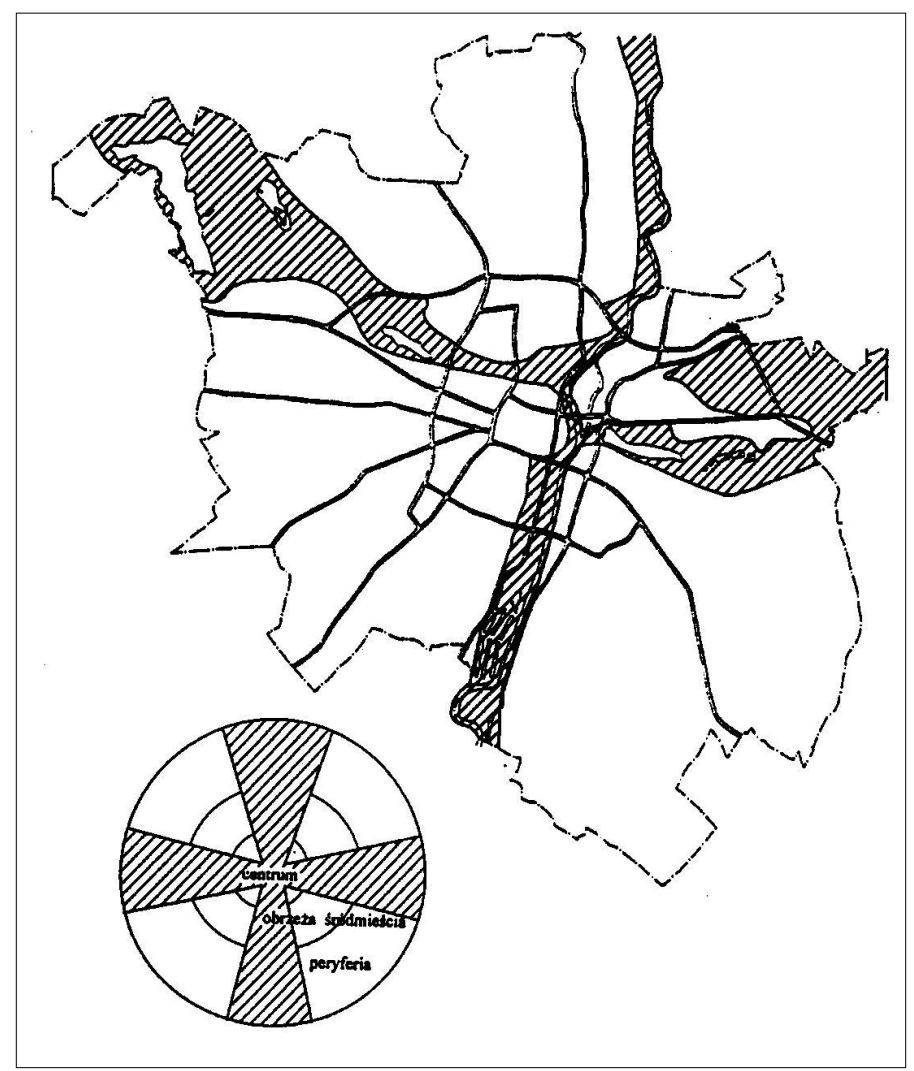

\section{Natural environment in long-term conceptions and plans of the city's development}

Environmental quality has long been a concern of the Poznań authorities in their attempts to adjust the city's spatial structure, on the one hand, to its physiographic conditions and on the other, to the changing population number and the economic changes of the recent years.

In the 1994 Local General Plan of Poznań's spatial development, much space is devoted to the urban greenery issue. The plan gives detailed instructions as to the management and protection of particularly important and valuable green spaces, both legally pro- 
tected ones (ecological land uses, nature reserves, nature-landscape complexes), and those essential for natural-cultural identity or featuring spontaneous vegetation. Much space is devoted to the existing and planned green wedges (Mierzejewska, 2001).

Issues connected with the conservation and development of green spaces featured also in the "Environment for the Residents" and "Poznan - a Healthy City" actions, as well as in the Programme of the Strategic Development of the City of Poznań adopted for implementation in 1995. The first and basic aim of the strategy is an improvement in the state of the natural environment, the residents' living conditions, and public safety. What makes its achievement in relation to the environment even more important is the fact that Poznan is considered among ecologically threatened areas (cf. Efekty wdrażania ...). This means that the extent and intensity of environmental pollution registered in the city exceeds acceptable limits, particularly water contamination and the noise level. To improve the air, the following measures have been taken over the recent years:

- the development of the heat distribution network,

- switching from the traditional source of heat in boiler-houses to gas or oil,

- modernisation and replacement of the bus stock in urban transport, and

- implementation of cleaner manufacturing technologies in factories.

These measures have contributed to a substantial decrease in the air pollution level in Poznań. Another factor has been the collapse or limitation of production of many environmentally burdensome industrial plants.

To reduce noise, acoustic screens have been built, but the city's needs far exceed its financial potential.

The biggest investment intended to improve the purity of surface waters has been the Central Sewage Treatment Plant for the City of Poznan, opened in 2001. However, the quality of the Warta river water will not improve radically until the towns located upstream have also undertaken similar measures. Protection programmes have also been worked out for all the major lakes within city limits, and the performance of the sewerage has been improved.

Steps have also been taken to reduce the amount of waste stored and to recover many valuable materials. The recycling is carried out by several specialised firms, including the Municipal Refuse Tip. Work has also been undertaken to ensure safe and environmentfriendly conditions of waste storage. To this end, at Suchy Las a biogas-fuelled power plant and a treatment plant have been built at the Municipal Refuse Tip, and its scarps have been secured against erosion.

Other environmental measures undertaken in Poznań include an improved water supply system and better water quality, laying out parks and restoration of the existing ones, limiting traffic in the city centre, and actions promoting pro-ecological behaviour among children and young people.

The main goal of the steps taken in the recent years to improve the state of the city's environment, however, has been not nature itself, but primarily the quality of life of Poznań residents. 


\section{City's nature as a factor of and limitation on its development}

The many functions that the natural elements play in the city and their beneficial effect on its spatial-functional structure, aesthetics, and sanitary conditions make it advisable to accommodate three basic rules in the city's spatial development (Mierzejewska, Parysek, 1998; Mierzejewska 2001):

1. an almost unconditional protection of green spaces against building and any change in the land use;

2. afforestation and tree-planting on all plots of land suitable for the purpose, and

3. the choice of land development forms appropriate for the neighbouring green spaces.

The necessity to protect urban natural elements is sometimes viewed as a limitation on the city's economic and spatial development. It often involves the conservation of the current state of investment in many parts of the city, and also implies restrictions following from the choice of a neighbourhood for protected areas.

The most friendly neighbourhoods for protected areas are certainly single- and multiple-family low-rise buildings, sport and recreational facilities, and transport facilities (streets, access roads, car parks). In the case of Poznań's many legally protected areas of high natural value, it is necessary to surround them with special buffer zones or, if possible, to include them in the existing or planned green wedges (Mierzejewska, Parysek, 2001; Mierzejewska, 2001).

A limiting factor in the city's development is allotments scattered in its various parts. The law in force protects these forms of land use against being put to other uses, but the owners' common sense and the city's needs should gradually lead to a change in the function of this category of greenery. A substantial proportion of allotments situated in the compact part of the city neighbour on industrial plants or heavy-traffic routes. The vegetables and fruits growing there are generally not fit for eating, and spending much time in those areas can do some persons more harm than good. That is why it is believed that they should be gradually included in the existing and developed green wedges, or redesigned for parks, residential housing, and service buildings.

However, nature in the city cannot be merely perceived as a growth limitation, but also as a major factor of development. 'Green cities' of themselves tend to attract people eager to visit or live in them. Attractive, readily accessible green spaces will also be interesting to entrepreneurs investing in tourism and recreation (Mierzejewska, Parysek, 2001).

This is what has happened in the recent years to an area called Malta, which embraces the Biała Góra woodland complex, the Cybina valley, and the artificial Lake Malta. One can find here a regatta racecourse where world-ranking competitions are held, an artificial skiing and sledging slope, a tourist-equipment hire centre, many quick-eating places, and other. Malta is a place where a great many events, both sporting and cultural, are organised (Mierzejewska 1998). Still waiting to be developed are thermal saline-bromine springs $\left(42{ }^{\circ} \mathrm{C}\right)$, whose resources and properties are enough to sustain a major recreationaltreatment complex. Attractive building sites can also be found on the shores of lakes Kiekrz 
and Strzeszyn, but ecological reasons and their present development (a rather dense building pattern) suggest a very careful development policy here.

With some green spaces, however, it would be advisable to permit the construction of small hotels and eating places. Also, the Poznan forts should be developed and made accessible to the public for walking; they should be included in the system of the Poznan walking and excursion routes.

\section{Role of public opinion in the shaping of Poznań's natural environment}

In accordance with the principles of sustainable development as laid down in the Rio Declaration, the UN Charter of Human Rights, and the Constitution of the Polish Republic, the subject of sustainable development is man, who has a right to live healthily and productively in harmony with nature. Hence, human beings are entitled to take an active part in the making of decisions affecting their living conditions. That is why public opinion should be taken into consideration in the shaping of urban green spaces. Attention should be paid especially to people's needs and to what they think about the measures taken by the city authorities.

In every public-opinion poll carried out by the Poznan City Office so far, care for the city's natural environment has been indicated as one of the priorities. The respondents are aware of the importance of the natural elements as a basis of the city's ecological system, but have a rather low opinion about their general state. On the scale of 2 (the lowest) to 5 (the highest), the arithmetic mean of marks scored by Poznan's recreation sites is 3.46 ; by lawns and squares, 3.3; the tidiness of the suburban woodlands, 3.06; and the purity of lakes in and around Poznań, 2.88 (Matczak, 1998). This means that the residents are aware of the neglect of their city's green areas and that they are very critical of this situation (Cichocki, 1988). Another major issue indicated by those polled is the protection of the citizens against crime, especially so that they rank parks among the most dangerous places after dark (Cichocki, 1988; Cichocki, Podemski, 1998). The improvement in the safety of green spaces seems to be a priority with the respondents, but it has never even appeared in the city's development plans and strategies.

The respondents have also been asked about allotments. As has already been mentioned, they are often situated in locations clashing with their economic-recreational function. The respondents' opinion is unequivocal: more than $75 \%$ are for moving the allotments to city margins and redeveloping the old ones as recreational sites. Only a few (more than 9\%) are not bothered by their location near heavy-traffic routes (Mierzejewska, 2001).

The analysis of the survey research allows one to conclude that nature is of great value to Poznan residents: over $83 \%$ of those polled have declared that the most important criterion for them when choosing a potential place of residence would be the closeness of green spaces. However, for those spaces to perform their ascribed functions, they should be moulded not only from the point of view of the city's spatial structure, but also the inhabitants' needs. 


\section{CONCLUSION}

Like other Polish cities, Poznan is obliged to conduct a development policy consistent with the sustainable development concept. It is especially important in the case of this city, which has been among the most dynamically developing ones in the country over the recent years. In this situation, establishing the correct proportions and relations between built-up areas and natural elements is of paramount importance. Hence, the approaches acceptable in planning and plan implementation are those of stewardship or, to a lesser degree, natureorientation.

The present socio-economic situation of most Polish towns, however, including Poznań, makes them adopt an improvement in the state of the natural environment as their basic target treated as a starting point for sustainable development. The realisation of this goal involves huge financial outlays for the construction and modernisation of infrastructure. Still, alongside these measures, steps should be taken to protect the natural elements found in the cities, especially their greenery.

Taking into consideration the many functions of the urban green spaces and their beneficial effect on the health of the residents, Poznań's sustainable development plans should accommodate the following targets (Mierzejewska, Parysek 1998; Mierzejewska 2001):

1. increasing the degree of integration of built-up areas in the city centre and on housing estates with the greenery,

2. developing the green wedges by expanding them and making them denser, especially in the city centre,

3. reducing investment in the green wedge areas to a bare minimum,

4. absolute protection against changes in the use of green spaces in the city centre and peripheral ones of historic importance,

5. a gradual switching of allotments located near industrial plants and heavy-traffic roads to other uses,

6. the planting of trees and shrubs on housing estates and hedges along the principal exit roads and railways,

7. protecting unique green spaces and those of historic merit, and

8. improving the tidiness and safety of those spaces.

These measures will improve the aesthetic and landscape value of Poznań, its resi-dents will enjoy better sanitary conditions and more recreational opportunities, and the city's development will be more balanced.

\section{Literature}

Achterberg W., 1986; Gronden van moreel respect voor de natuur. (W:) Milieufilosofie tussen theorie en praktijk: van ekologisch perspectief naar maatschappelijke toepassing (red. J. van Arkel).

Bauman R., 1991: Domy w zieleni. Arkady, Warszawa. 
Chojnicki Z., 1971: Model wzajemnych zależności między systemem społeczno-ekonomicznym a środowiskiem geograficznym. Poznańskie Roczniki Ekonomiczne, t. 24, 57-67.

Chojnicki Z., 1988: Koncepcja terytorialnego systemu społecznego. Przegląd Gograficzny 60/4, 491-507.

Cichocki R., 1988: Ogólna ocena życia w Poznaniu. Główne problemy miasta. (W:) Życie w Poznaniu 1997. Poznaniacy o swoim mieście. (red. R. Cichocki, K. Podemski). Poznańska Drukarnia Naukowa, Poznań.

Cichocki R., Podemski K., 1998: Ocena stanu bezpieczeństwa. (W:) Życie w Poznaniu 1997. Poznaniacy o swoim mieście. (red. R. Cichocki, K. Podemski). Poznańska Drukarnia Naukowa, Poznań.

Czarnecki W., 1961: Planowanie miast i osiedli. T.III. Tereny zielone. PWN, Warszawa.

Czerwieniec M., Lewińska J., 1996: Zieleń w mieście. Instytut Gospodarki Przestrzennej i Komunalnej, Warszawa.

Efekty wdrażania programu strategicznego rozwoju miasta Poznania w latach 1995-1997. Urząd Miasta, Poznań 1998.

Gacka-Grześkiewicz E., Różycka W., 1975: Obszary chronione (parki krajobrazowe i strefy chronionego krajobrazu) a strunktura przestrzenna aglomeracji. Warszawa.

Gaczek W. M., 1992: Zmiany użytkowania terenów miejskich Poznania w okresie powojennym. (W:) Gospodarka przestrzenią miast i gmin w regionie Wielkopolski (red. R. Pawuła-Piwowarczyk). Politechnika Poznańska, Poznań, 63-76.

Kepel A., 2002: Poznańskie tereny zieleni. (W:) Kronika Miasta Poznania. Wśród zwierząt i roślin. poznańska Drukarnia Naukowa, Poznań.

Matczak P., 1998: Stan środowiska w opinii mieszkańców Poznania. (W:) Życie w Poznaniu 1997. Poznaniacy o swoim mieście. (red. R. Cichocki, K. Podemski). Poznańska Drukarnia Naukowa, Poznań.

Mierzejewska L., 2001: Tereny zielone w strukturze przestrzennej Poznania. PTPN. Poznań.

Mierzejewska L. Parysek J., 2001: Environment and Planning, or possible approaches to the environment in physical planning. (W:) Geographia Polonica, vol. 74, no.1.

Mierzejewska L., 1998: „Malta”-obszar rekreacyjny i atrakcja turystyczna Poznania. (W:) Kwartalnik Geograficzny. Pismo Edukacyjne nr 4 (8)/98. Wydawnictwo M. Rożak, Gdańsk.

Mierzejewska L., Parysek J., 1998: Tereny zielone oraz ich miejsce i funkcje w strukturze przestrzennej miasta. (W:) Podstawy gospodarczej polityki miasta. Studium Poznania. (red. R. Domański). Biuletyn KPZK. zeszyt 181. PAN, Warszawa, 189-214.

Myczkowski S., Grabowski A., 1974: Zieleń osiedlowa i wypoczynkowa miasta Krakowa. Sozologia i sozotechnika. z.2. Zeszyty Naukowe Akademii Górniczo-Hutniczej im. S. Staszica nr 361.

Parysek J., 1997: Podstawy gospodarki lokalnej. Wydawnictwo Naukowe UAM. Poznań Regulski J., 1982. Ekonomia miasta, PWE Warszawa.

Van der Wurff R., 1992: Sustainable Development. A Cultural Approch. A report for the FAST Programme, vol 21 